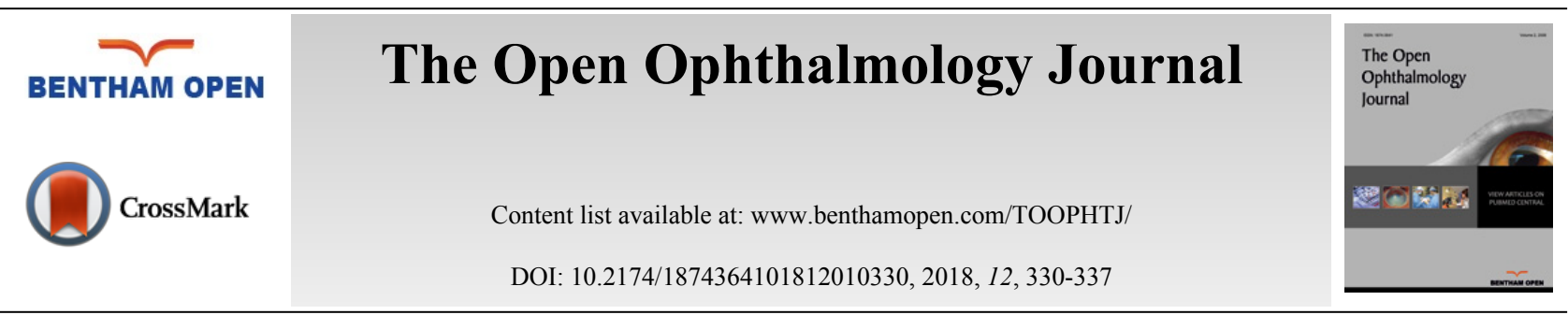

RESEARCH ARTICLE

\title{
The Effect Of Topical Antihistamines Used Single Dose Daily in
} Allergic Conjunctivitis

\author{
Hakika Erdogan ${ }^{*}$ and Ozlem Cam \\ Department of Medicine, Faculty of Ophthalmology, Maltepe University, Maltepe, Istanbul, Turkey
}

Received: October 19, 2018

Revised: November 30, 2018

Accepted: December 03, 2018

\section{Abstract: \\ Background and Objective:}

To evaluate the efficacy of $0.2 \%$ olopatadine and to compare olopatadine $0.1 \%$, ketotifen $0.025 \%$ and emadastine $0.05 \%$ in the treatment of allergic conjunctivitis.

\section{Methods:}

In this retrospectively designed study, we investigated the files of patients who had been diagnosed with perineal or seasonal allergic conjunctivitis in the teaching hospital of Maltepe University between April 2017 and July 2017. We divided the patients into four groups. The patients in each group had similar symptoms and scores before medication. The first, second, third and fourth groups were prescribed olapatadine $0.1 \%$, olopatadine $0.2 \%$, ketotifen $0.025 \%$ and emedastine $0.05 \%$, respectively. We evaluated the symptoms and signs of the patients on the 15 th day after treatment, and compared the results between the groups.

\section{Results:}

We investigated the files of 80 patients. There were 20 patients in each group. We evaluated the symptoms and finding scores after treatment. The symptoms and findings of allergic conjunctivitis had improved in all the four groups. There was no difference in the treatment responses between the four groups.

\section{Conclusion:}

Olopatadine $0.2 \%$, olopatadine $0.1 \%$, ketotifen $0.025 \%$ and emedastine $0.05 \%$ were all equally effective in improving the signs and symptoms of allergic conjunctivitis.

Keywords: Allergic conjunctivitis, Antihistamines, Mast cell stabilization, Olopatadine, Ketotifen, Emedastine.

\section{INTRODUCTION}

Ocular allergy is a common benign ocular disease which threatens sight only very rarely. However, it may reduce the quality of life significantly [1].Ocular allergy is divided into four groups: Allergic Conjunctivitis (AC), atopic keratoconjunctivitis, vernal conjunctivitis and giant cell conjunctivitis. AC is a conjunctival inflammatory disease associated with the type 1 allergic reaction. AC usually occurs bilaterally, takes either the seasonal form or the perineal form [2] and is the most common type of ocular allergy [3]. While seasonal allergies occur annually during a specific season, perineal allergies occur chronically and the major antigens to which they are connected are house-dust-mites. AC currently an important problem for adults [4] is more prevalent in young people [2].

Allergens lead to degranulation in the mast cells via IGE, resulting in the release among many proinflammatory cytokines primarily of histamine. After the inflammatory reaction causing the processes of vasodilatation, increased

* Address correspondence to this author at the Department of Medicine, Faculty of Ophthalmology, Maltepe University, Maltepe, Istanbul, Turkey; Tel: +90 50587265 52; E-mail: dr.gercek@yahoo.com 
vascular permeability and leukocyte chemotaxis, symptoms and signs of AC occur [5].

$\mathrm{AC}$ is characterised by the symptoms of itching, sensations of the presence of a foreign body, photophobia and tearing. The most frequent conjunctival findings are conjunctival hyperemia and papillary formation [2].

The drugs most commonly used in AC treatment are topical antihistamines and topical mast cell stabilizers [6]. Another option for topical medications is dual agents with both antihistaminic effects and mast cell stabilization, and other commonly preferred agents for treatment include topical steroids, nonsteroidal anti-inflammatory drops and immunomodulators [7]. Particularly in resistant cases, topical corticosteroids can be used for a short period of time. Nonsteroidal is nonetheless more effective than placebo. Systemic antihistamines and steroids may be used in patients with systemic symptoms [1].

Olopatadine and ketotifen are dual agents, both blockading $\mathrm{H} 1$ receptors and stabilizing mast cells. Emedastine blocks $\mathrm{H} 1$ receptors only [8].

Olopatadine $0.1 \%$, ketotifen $0.025 \%$ and emedastine $0.05 \%$ are used twice daily, while the new generation of olopatadine $0.2 \%$ drops are used once a day. A daily dose of olopatadine $0.2 \%$ alleviates the symptoms of allergy with a 16-hour mechanism of action [9].

Our study aimed at comparing the sign and symptoms of patients with symptomatic AC after treatment with olopatadine $0,2 \%\left(\right.$ ofnol s $\mathrm{s}^{\circledR}$ ), olopatadine $0.1 \%$ (patanol $^{\circledR}$ ), ketotifen $0.025 \%$ (zaditen $^{\circledR}$ ) and emedastine $0.05 \%$ (emadine $^{\circledR}$ ) and to evaluate if olopatadine $0.2 \%$ use once daily is as effective as other drops use twice daily for AC treatment.

\section{MATERIAL AND METHODS}

In this retrospective study, our subjects comprised patients diagnosed with AC in Maltepe University Medical Faculty Hospital between April 2017 and July 2017. On visiting the hospital, subjects presented with itching, photophobia and eye pain. Patients treated with olopatadine $0.1 \%$, olopatadine $0.2 \%$, ketotifen $0.025 \%$ and emedastine $0.05 \%$, and had the clinical symptoms and signs of AC, were included in the study. Papilla, conjunctival edema and redness were accepted as the main signs, and itching, photophobia, tearing and a sensation of the presence of a foreign body (discomfort) were accepted as the main symptoms. Two weeks after the onset of treatment, drug effects were investigated from the patients' files to evaluate the changes in symptoms and signs. Symptoms and signs were graded as no evidence, mild, moderate and severe using Özcan et al.'s table [10].

The inclusion criteria were patients:

1. whose objective and subjective symptoms were completely graded and written in their files

2. who did not currently use systemic antiallergic drugs

3. who did not have any systemic disease

4. who had conjunctivitis without any other eye disease

5. who had not used topical and systemic antiallergic drugs for one month

The exclusion criteria were patients:

1. who did not attend follow-up examination

2. who did not adhere to their prescribed medication

3. for whom file information was missing

Our institutional review board (Ethics Committee of Maltepe University) approved the study protocol before our study started, and it adhered to the tenets of the Declaration of Helsinki.

Patients with similar objective and subjective symptoms before treatment fulfilling the specified criteria were divided into four groups, each comprising 20 patients. Severity of disease for each group was similar. They were examined the same time of the same year. Thus, the possibility of exposure to the similar environmental antigen was increased. The first group included olopatadine $0.1 \%$ users, the second group included olopatadine $0.2 \%$ users, the third group included ketotifen $0.025 \%$ users and the fourth group included emedastine $0.05 \%$ users. We evaluated the objective and subjective symptoms of 80 patients before and after 15 days of the treatment. 


\subsection{Statistical Analysis}

We used the mean, standard deviation, median, lowest, highest, frequency and ratio values in the descriptive statistics of the data, the chi-square test in the analysis of qualitative independent data and the Fischer test in the case where chi-square test conditions were not provided for. The analysis of the dependent qualitative data was done using McNemar's test. The SPSS 22.0 programme was used in all the analyses

\section{RESULTS}

In the present study 80 patients were included. Table $\mathbf{1}$ shows the age and gender distribution of the patients in group I, group II, group III and, group IV. No significant difference was found in age and sex between the groups.

Table 1. Demographic characteristics of cases.

\begin{tabular}{|c|c|c|c|c|c|c|c|c|c|c|c|c|}
\hline & - & - & \multicolumn{2}{|c|}{ Grup I } & \multicolumn{2}{|c|}{ Grup II } & \multicolumn{2}{|c|}{ Grup III } & \multicolumn{2}{|c|}{ Grup IV } & \multicolumn{2}{|l|}{$p$} \\
\hline \multirow{2}{*}{\multicolumn{2}{|c|}{ Age }} & $\operatorname{Mean} \pm$ sd & \multicolumn{2}{|c|}{$20,7 \pm 13,6$} & \multicolumn{2}{|c|}{$16,3 \pm 11,2$} & \multicolumn{2}{|c|}{$16,4 \pm 9,7$} & \multicolumn{2}{|c|}{$18,8 \pm 11,2$} & \multirow{2}{*}{0,556} & \multirow{2}{*}{$\mathrm{K}$} \\
\hline & & Median & & & & & & & & & & \\
\hline \multirow{2}{*}{ Sex } & Female & $n-\%$ & 13 & $65 \%$ & 10 & $50 \%$ & 9 & $45 \%$ & 14 & $70 \%$ & \multirow{2}{*}{0,324} & \multirow{2}{*}{$x^{2}$} \\
\hline & Male & $n-\%$ & 7 & $35 \%$ & 10 & $50 \%$ & 11 & $55 \%$ & 6 & $30 \%$ & & \\
\hline
\end{tabular}

${ }^{\mathrm{K}}$ Kruskal-wallis (Mann-whitney u test) $/{ }^{z^{2}}$ Chi-square test

Group 1 olapathadine $0.1 \%$

Group 2 olapathadine $0.2 \%$

Group 3 ketotifen ketotifen $0.025 \%$

Group 4 emedastine $0.05 \%$

When pre-medication symptoms and findings was evaluated, the indices of severe pruritus, irritation, discomfort of the eye and photophobia were $27.5 \%, 18.8 \%, 7.5 \%$ and $5 \%$, respectively. We found severe papillary hypertrophy in $15 \%$ of patients, and severe hyperemia in $13 \%$ of the patients. Severe chemosis and lid edema were absent in all the patients. We found mild grade chemosis in $16.3 \%$ of the patients only, and mild lid edema in $1 \%$ of the patients only. Table 2 describes the pre- and post-treatment symptoms and findings of the patients.

Table 2. Pre- and post-treatment symptoms and findings scores of the patients.

\begin{tabular}{|c|c|c|c|c|c|c|}
\hline- & - & - & Min-Max & Median & \multicolumn{2}{|c|}{$\operatorname{Mean} \pm$ sd } \\
\hline Age & - & - & $5,0-55,0$ & 14,0 & \multicolumn{2}{|c|}{$18,0 \pm 11,4$} \\
\hline \multirow{2}{*}{ Sex } & \multirow{2}{*}{-} & Female & \multirow{2}{*}{-} & \multirow{2}{*}{-} & 46 & $57,5 \%$ \\
\hline & & Male & & & 34 & $42,5 \%$ \\
\hline \multirow{5}{*}{ Itching } & Before & Mild & \multirow{3}{*}{-} & \multirow{3}{*}{-} & 7 & $8,8 \%$ \\
\hline & Medication & Moderate & & & 51 & $63,8 \%$ \\
\hline & - & Severe & & & 22 & $27,5 \%$ \\
\hline & \multirow{2}{*}{ After Medication } & None & \multirow{2}{*}{-} & \multirow{2}{*}{-} & 46 & $57,5 \%$ \\
\hline & & Mild & & & 34 & $42,5 \%$ \\
\hline \multirow{6}{*}{ Tearing } & Before & Mild & \multirow{3}{*}{-} & \multirow{3}{*}{-} & 25 & $31,3 \%$ \\
\hline & Medication & Moderate & & & 40 & $50,0 \%$ \\
\hline & - & Severe & & & 15 & $18,8 \%$ \\
\hline & \multirow{3}{*}{ After Medication } & None & \multirow{3}{*}{-} & \multirow{3}{*}{-} & 54 & $67,5 \%$ \\
\hline & & Mild & & & 25 & $31,3 \%$ \\
\hline & & Moderate & & & 1 & $1,3 \%$ \\
\hline \multirow{5}{*}{ Discomfort } & Before & Mild & \multirow{3}{*}{-} & \multirow{3}{*}{-} & 35 & $43,8 \%$ \\
\hline & Medication & Moderate & & & 39 & $48,8 \%$ \\
\hline & - & Severe & & & 6 & $7,5 \%$ \\
\hline & \multirow{2}{*}{ After Medication } & None & \multirow{2}{*}{-} & \multirow{2}{*}{-} & 54 & $67,5 \%$ \\
\hline & & Mild & & & 26 & $32,5 \%$ \\
\hline \multirow{5}{*}{ Photophobia } & Before & Mild & \multirow{3}{*}{-} & \multirow{3}{*}{-} & 34 & $42,5 \%$ \\
\hline & Medication & Moderate & & & 42 & $52,5 \%$ \\
\hline & - & Severe & & & 4 & $5,0 \%$ \\
\hline & \multirow{2}{*}{ After Medication } & None & \multirow{2}{*}{-} & \multirow{2}{*}{-} & 65 & $81,3 \%$ \\
\hline & & Mild & & & 15 & $18,8 \%$ \\
\hline
\end{tabular}




\begin{tabular}{|c|c|c|c|c|c|c|}
\hline- & - & - & Min-Max & Median & & \pm sd \\
\hline \multirow{5}{*}{ Hyperemia } & Before & Mild & \multirow{3}{*}{ - } & \multirow{3}{*}{ - } & 18 & $22,5 \%$ \\
\hline & Medication & Moderate & & & 49 & $61,3 \%$ \\
\hline & - & Severe & & & 13 & $16,3 \%$ \\
\hline & \multirow{2}{*}{ After Medication } & None & \multirow{2}{*}{-} & \multirow{2}{*}{ - } & 74 & $92,5 \%$ \\
\hline & & Mild & & & 6 & $7,5 \%$ \\
\hline \multirow{6}{*}{ Papillae } & Before & Mild & \multirow{3}{*}{ - } & \multirow{3}{*}{-} & 13 & $16,3 \%$ \\
\hline & Medication & Moderate & & & 52 & $65,0 \%$ \\
\hline & - & Severe & & & 15 & $18,8 \%$ \\
\hline & \multirow{3}{*}{ After Medication } & None & \multirow{3}{*}{-} & \multirow{3}{*}{-} & 55 & $68,8 \%$ \\
\hline & & Mild & & & 22 & $27,5 \%$ \\
\hline & & Moderate & & & 3 & $3,8 \%$ \\
\hline \multirow{4}{*}{ Chemosis } & Before & None & \multirow{2}{*}{-} & \multirow{2}{*}{ - } & 67 & $83,8 \%$ \\
\hline & Medication & Mild & & & 13 & $16,3 \%$ \\
\hline & \multirow{2}{*}{ After Medication } & None & \multirow{2}{*}{-} & \multirow{2}{*}{-} & 76 & $95,0 \%$ \\
\hline & & Mild & & & 4 & $5,0 \%$ \\
\hline \multirow{4}{*}{ Lid Edema } & Before & None & \multirow{2}{*}{-} & \multirow{2}{*}{-} & 71 & $88,8 \%$ \\
\hline & Medication & Mild & & & 9 & $11,3 \%$ \\
\hline & \multirow{2}{*}{ After Medication } & None & \multirow{2}{*}{-} & \multirow{2}{*}{ - } & 79 & $98,8 \%$ \\
\hline & & Mild & & & 1 & $1,3 \%$ \\
\hline
\end{tabular}

The patients were divided into four groups according to the medication they were given. The first group of patients were given $0.1 \%$ olopatadine, the second group of patients were given $0.2 \%$ olopatadine which is once daily instillation drop, the third group of patients were given $0.025 \%$ ketotifen and emedastine $0.05 \%$ was given to the fourth group. There were no differences between the four groups in the pre-treatment symptoms and findings so the severity of disease for each group was similar $(p>0.05)$ as shown Tables $\mathbf{3}$ and $\mathbf{4}$.

We observed a significant improvement in the symptom and findings in all four groups after treatment compared with those before treatment (intragroup), but observed no difference between the four groups in the findings and symptoms after treatment (intergroup) as shown Tables $\mathbf{3}$ and $\mathbf{4}$.

\section{Table 3. Symptoms scores for each group.}

\begin{tabular}{|c|c|c|c|c|c|c|c|c|c|c|c|}
\hline \multicolumn{2}{|c|}{-} & \multicolumn{2}{|c|}{ Grup I } & \multicolumn{2}{|c|}{ Grup II } & \multicolumn{2}{|c|}{ Grup III } & \multicolumn{2}{|c|}{ Grup IV } & \multirow{2}{*}{\multicolumn{2}{|c|}{$p$}} \\
\hline- & - & $\mathbf{n}$ & $\%$ & $\mathbf{n}$ & $\%$ & $\mathbf{n}$ & $\%$ & $\mathbf{n}$ & $\%$ & & \\
\hline \multicolumn{2}{|c|}{ Itching } & - & - & - & - & - & - & - & - & - & \\
\hline \multirow{3}{*}{ Before Medication } & Mild & 3 & $15,0 \%$ & 0 & $0,0 \%$ & 2 & $10,0 \%$ & 2 & $10,0 \%$ & \multirow{3}{*}{0,430} & \\
\hline & Moderate & 13 & $65,0 \%$ & 12 & $60,0 \%$ & 12 & $60,0 \%$ & 14 & $70,0 \%$ & & $x^{2}$ \\
\hline & Severe & 4 & $20,0 \%$ & 8 & $40,0 \%$ & 6 & $30,0 \%$ & 4 & $20,0 \%$ & & \\
\hline \multirow{2}{*}{ After Medication } & None & 11 & $55,0 \%$ & 11 & $55,0 \%$ & 12 & $60,0 \%$ & 12 & $60,0 \%$ & \multirow{2}{*}{0,977} & \\
\hline & Mild & 9 & $45,0 \%$ & 9 & $45,0 \%$ & 8 & $40,0 \%$ & 8 & $40,0 \%$ & & \\
\hline \multicolumn{2}{|c|}{ Beforel After Difference $p$} & 0,001 & $\mathrm{~N}$ & 0,001 & $\mathrm{~N}$ & 0,001 & $\mathrm{~N}$ & 0,001 & $\mathrm{~N}$ & & \\
\hline \multicolumn{2}{|c|}{ Tearing } & - & - & - & - & - & - & - & - & - & - \\
\hline \multirow{3}{*}{ Before Medication } & Mild & 9 & $45,0 \%$ & 4 & $20,0 \%$ & 6 & $30,0 \%$ & 6 & $30,0 \%$ & 0,404 & \\
\hline & Moderate & 10 & $50,0 \%$ & 10 & $50,0 \%$ & 9 & $45,0 \%$ & 11 & $55,0 \%$ & \multirow{2}{*}{\multicolumn{2}{|c|}{-}} \\
\hline & Severe & 1 & $5,0 \%$ & 6 & $30,0 \%$ & 5 & $25,0 \%$ & 3 & $15,0 \%$ & & \\
\hline \multirow{3}{*}{ After Medication } & None & 13 & $65,0 \%$ & 15 & $75,0 \%$ & 13 & $65,0 \%$ & 13 & $65,0 \%$ & \multirow{3}{*}{0,877} & \\
\hline & Mild & 7 & $35,0 \%$ & 5 & $25,0 \%$ & 6 & $30,0 \%$ & 7 & $35,0 \%$ & & \\
\hline & Moderate & 0 & $0,0 \%$ & 0 & $0,0 \%$ & 1 & $5,0 \%$ & 0 & $0,0 \%$ & & \\
\hline \multicolumn{2}{|c|}{ Beforel After Difference $p$} & 0,000 & N & 0,000 & N & 0,000 & N & 0,000 & N & & \\
\hline \multicolumn{2}{|c|}{ Discomfort } & - & - & - & - & - & - & - & - & - & - \\
\hline \multirow{3}{*}{ Before Medication } & Mild & 10 & $50,0 \%$ & 8 & $40,0 \%$ & 11 & $55,0 \%$ & 6 & $30,0 \%$ & \multirow{3}{*}{\multicolumn{2}{|c|}{0,272}} \\
\hline & Moderate & 8 & $40,0 \%$ & 9 & $45,0 \%$ & 8 & $40,0 \%$ & 14 & $70,0 \%$ & & \\
\hline & Severe & 2 & $10,0 \%$ & 3 & $15,0 \%$ & 1 & $5,0 \%$ & 0 & $0,0 \%$ & & \\
\hline \multirow{2}{*}{ After Medication } & None & 13 & $65,0 \%$ & 14 & $70,0 \%$ & 12 & $60,0 \%$ & 15 & $75,0 \%$ & \multirow{2}{*}{\multicolumn{2}{|c|}{0,768}} \\
\hline & Mild & 7 & $35,0 \%$ & 6 & $30,0 \%$ & 8 & $40,0 \%$ & 5 & $25,0 \%$ & & \\
\hline \multicolumn{2}{|c|}{ Beforel After Difference $p$} & 0,000 & $\mathrm{~N}$ & 0,000 & $\mathrm{~N}$ & 0,001 & $\mathrm{~N}$ & 0,000 & $\mathrm{~N}$ & - & \\
\hline
\end{tabular}


(Table 3) contd.....

\begin{tabular}{|c|c|c|c|c|c|c|c|c|c|c|c|}
\hline \multicolumn{2}{|l|}{-} & \multicolumn{2}{|c|}{ Grup I } & \multicolumn{2}{|c|}{ Grup II } & \multicolumn{2}{|c|}{ Grup III } & \multicolumn{2}{|c|}{ Grup IV } & \multirow{2}{*}{\multicolumn{2}{|c|}{$p$}} \\
\hline- & - & $\mathbf{n}$ & $\%$ & $\mathbf{n}$ & $\%$ & $\mathbf{n}$ & $\%$ & $\mathbf{n}$ & $\%$ & & \\
\hline \multicolumn{2}{|c|}{ Photophobia } & - & - & - & - & - & - & - & - & - & - \\
\hline \multirow{3}{*}{ Before Medication } & Mild & 13 & $65,0 \%$ & 5 & $25,0 \%$ & 5 & $25,0 \%$ & 11 & $55,0 \%$ & \multirow{3}{*}{0,461} & \multirow{3}{*}{$\mathrm{x}^{2}$} \\
\hline & Moderate & 7 & $35,0 \%$ & 15 & $75,0 \%$ & 11 & $55,0 \%$ & 9 & $45,0 \%$ & & \\
\hline & Severe & 0 & $0,0 \%$ & 0 & $0,0 \%$ & 4 & $20,0 \%$ & 0 & $0,0 \%$ & & \\
\hline \multirow{2}{*}{ After Medication } & None & 14 & $70,0 \%$ & 16 & $80,0 \%$ & 17 & $85,0 \%$ & 18 & $90,0 \%$ & \multirow{2}{*}{0,412} & \multirow{2}{*}{$x^{2}$} \\
\hline & Mild & 6 & $30,0 \%$ & 4 & $20,0 \%$ & 3 & $15,0 \%$ & 2 & $10,0 \%$ & & \\
\hline \multicolumn{2}{|c|}{ Beforel After Difference $p$} & 0,000 & $\mathrm{~N}$ & 0,000 & $\mathrm{~N}$ & 0,001 & $\mathrm{~N}$ & 0,000 & $\mathrm{~N}$ & - & - \\
\hline
\end{tabular}

$\mathrm{X}^{2}$ Chi-square test $/{ }^{\mathrm{N}} \mathrm{Mc}-\mathrm{Nemar}$ Test

Table 4. Finding scores for each group

\begin{tabular}{|c|c|c|c|c|c|c|c|c|c|c|c|}
\hline \multicolumn{2}{|l|}{-} & \multicolumn{2}{|c|}{ Grup I } & \multicolumn{2}{|c|}{ Grup II } & \multicolumn{2}{|c|}{ Grup III } & \multicolumn{2}{|c|}{ Grup IV } & \multirow{2}{*}{\multicolumn{2}{|c|}{$p$}} \\
\hline- & - & $\mathbf{n}$ & $\%$ & $\mathbf{n}$ & $\%$ & $\mathbf{n}$ & $\%$ & $\mathbf{n}$ & $\%$ & & \\
\hline \multicolumn{2}{|c|}{ Hyperemia } & - & - & - & - & - & - & - & - & - & - \\
\hline \multirow{3}{*}{ Before Medication } & Mild & 4 & $20,0 \%$ & 3 & $15,0 \%$ & 4 & $20,0 \%$ & 7 & $35,0 \%$ & \multirow{3}{*}{0,675} & \multirow{3}{*}{$x^{2}$} \\
\hline & Moderate & 11 & $55,0 \%$ & 14 & $70,0 \%$ & 13 & $65,0 \%$ & 11 & $55,0 \%$ & & \\
\hline & Severe & 5 & $25,0 \%$ & 3 & $15,0 \%$ & 3 & $15,0 \%$ & 2 & $10,0 \%$ & & \\
\hline \multirow{2}{*}{ After Medication } & None & 19 & $95,0 \%$ & 19 & $95,0 \%$ & 18 & $90,0 \%$ & 18 & $90,0 \%$ & \multirow{2}{*}{0,868} & \multirow{2}{*}{$x^{2}$} \\
\hline & Mild & 1 & $5,0 \%$ & 1 & $5,0 \%$ & 2 & $10,0 \%$ & 2 & $10,0 \%$ & & \\
\hline \multicolumn{2}{|c|}{ Before/ After Difference $p$} & 0,000 & $\mathrm{~N}$ & 0,000 & $\mathrm{~N}$ & 0,000 & $\mathrm{~N}$ & 0,000 & $\mathrm{~N}$ & - & - \\
\hline \multicolumn{2}{|c|}{ Papillae } & - & - & - & - & - & - & - & - & - & - \\
\hline \multirow{3}{*}{ Before Medication } & Mild & 5 & $25,0 \%$ & 4 & $20,0 \%$ & 1 & $5,0 \%$ & 3 & $15,0 \%$ & \multirow{3}{*}{0,360} & \multirow{3}{*}{$x^{2}$} \\
\hline & Moderate & 9 & $45,0 \%$ & 13 & $65,0 \%$ & 13 & $65,0 \%$ & 17 & $85,0 \%$ & & \\
\hline & Severe & 5 & $25,0 \%$ & 3 & $15,0 \%$ & 6 & $30,0 \%$ & 0 & $0,0 \%$ & & \\
\hline \multirow{3}{*}{ After Medication } & None & 10 & $50,0 \%$ & 14 & $70,0 \%$ & 15 & $75,0 \%$ & 16 & $80,0 \%$ & \multirow{3}{*}{0,185} & \multirow{3}{*}{$x^{2}$} \\
\hline & Mild & 8 & $40,0 \%$ & 5 & $25,0 \%$ & 5 & $25,0 \%$ & 4 & $20,0 \%$ & & \\
\hline & Moderate & 2 & $10,0 \%$ & 1 & $5,0 \%$ & 0 & $0,0 \%$ & 0 & $0,0 \%$ & & \\
\hline \multicolumn{2}{|c|}{ Beforel After Difference $p$} & 0,002 & $\mathrm{~N}$ & 0,000 & $\mathrm{~N}$ & 0,000 & $\mathrm{~N}$ & 0,000 & $\mathrm{~N}$ & - & - \\
\hline \multicolumn{2}{|c|}{ Chemosis } & - & - & - & - & - & - & - & - & - & - \\
\hline \multirow{2}{*}{ Before Medication } & None & 18 & $90,0 \%$ & 18 & $90,0 \%$ & 17 & $85,0 \%$ & 14 & $70,0 \%$ & \multirow{2}{*}{1,000} & - \\
\hline & Mild & 2 & $10,0 \%$ & 2 & $10,0 \%$ & 3 & $15,0 \%$ & 6 & $30,0 \%$ & & - \\
\hline \multirow{2}{*}{ After Medication } & None & 19 & $95,0 \%$ & 19 & $95,0 \%$ & 19 & $95,0 \%$ & 19 & $95,0 \%$ & \multirow{2}{*}{0,267} & - \\
\hline & Mild & 1 & $5,0 \%$ & 1 & $5,0 \%$ & 1 & $5,0 \%$ & 1 & $5,0 \%$ & & - \\
\hline \multicolumn{2}{|c|}{ Before/ After Difference p } & 0,564 & $\mathrm{~N}$ & 0,564 & $\mathrm{~N}$ & 0,317 & $\mathrm{~N}$ & 0,059 & $\mathrm{~N}$ & - & - \\
\hline \multicolumn{2}{|c|}{ Lid Edema } & - & - & - & - & - & - & - & - & - & - \\
\hline Dofom Madiotion & None & 17 & $85,0 \%$ & 19 & $95,0 \%$ & 19 & $95,0 \%$ & 16 & $80,0 \%$ & 225 & $x^{2}$ \\
\hline Berore Medication & Mild & 3 & $15,0 \%$ & 1 & $5,0 \%$ & 1 & $5,0 \%$ & 4 & $20,0 \%$ & 0,225 & $x^{n}$ \\
\hline Aftor Madiotion & None & 19 & $95,0 \%$ & 20 & $100 \%$ & 20 & $100 \%$ & 20 & $100 \%$ & 1000 & $x^{2}+3 x-2$ \\
\hline Anter iviecicationt & Mild & 1 & $5,0 \%$ & 0 & $0,0 \%$ & 0 & $0,0 \%$ & 0 & $0,0 \%$ & 1,000 & a \\
\hline Beforel After 1 & nce $p$ & 0,317 & $\mathrm{~N}$ & 0,317 & $\mathrm{~N}$ & 0,317 & $\mathrm{~N}$ & 0,046 & $\mathrm{~N}$ & - & - \\
\hline
\end{tabular}

${ }^{2}$ Chi-square test $/{ }^{\mathrm{N}} \mathrm{Mc}-\mathrm{Nemar}$ Test

\section{DISCUSSION}

Allergic conjunctivitis causes severe ocular discomfort, significantly reducing the quality of life in patients. Since allergic conjunctivitis is a chronic condition, it also has serious economic effects [11].

Conjunctival inflammation should be well suppressed for this reason. It is commonly treated with topical ophthalmic formulations to reduce inflammation and to provide relief of symptoms. Topical treatments include eye drops with antihistamines, mast cell stabilizers, non-steroidal anti-inflammatory drugs and corticosteroids separately or combined. AC is usually accompanied by acute manifestations and typical signs and symptoms including itching, redness and tearing, the clinical signs and symptoms of allergic conjunctivitis, are mediated by the release of histamine by mast cells.

The action of histamines is inhibited by antihistamines, which blocks histamine $\mathrm{H} 1$ receptors and prevent 
vasoconstriction. In the early phase of the allergen, antihistaminic activity is required, while in the late phase, degranulation of the mast cells must be prevented.

Degranulation and the release of histamine are inhibited by mast cell stabilizers [12]. The most preferred antihistamines and mast cell stabilizers are prescribed for use twice a day [13]. A currently available dual agent aims to reduce the signs and symptoms of allergy with use once a day only. Single dose daily use of the drug may ensure compliance with the treatment of patient [14].

Many studies in the literature compare these topical antiallergics. In some studies no difference was found in response to treatments, and the drugs showed similar efficacy in symptomatic protection of the patients with AC for each drops installed two times a day [11, 15 - 17]. In contrast to these results, in the same studies ketotifen was proven to be superior to the other drops in relieving symptoms with active ocular allergies[18 - 21] while in the others, olapatadin was obseved to be more effective. [22, 23].

Previous clinical trial had found the effect of olopatadine $0.2 \%$, which was found to be significantly superior to the placebo in AC treatment [24]. And in some studies olapatadin $0.2 \%$ was found to be as safe and effective as olapatadine $0.1 \%$ in reducing Ac symptoms and findings [25 - 29]

In the present study, four molecules were compared with each other and tested whether olopatadine $0.2 \%$ drop, which is a single dose instillation a day had similar activity as that of other two dose instillation a day of antihistamine/mast cell stabilizers drops in improving symptoms and findings. In the literature there is no study comparing these 4 drugs in the same real-life conditions.

In the present study no difference was found between olopatadine $0.1 \%$, olopatadine $0.2 \%$, ketotifen $0.025 \%$ and emedastine $0.05 \%$. The varying results in the literature may depend on many factors. Some of the studies were conducted using animal models in a laboratory environment, allowing for precise knowledge of exactly what the allergen was and the duration of the contact time with the allergen. However, in real life, patients are in contact with allergens constantly and are not affected by only one allergen. Undiagnosed dry eyes and other lid diseases may be present in these studies, with effects on the treatment process and response to AC. The species and contact time of the allergen varies from country to country, with the result that comparisons of studies from different countries may lead to a misevaluation of drug efficacy. Patients' strict adherence to the drug regimen is unknown, especially if the studies are prospective. Symptoms of the same severity may cause different responses in different patients espectially since the question of symptoms is based on subjective responses.

In order to eliminate the many factors above, the study was performed with patients who were inhabitant of the same area and had similar symptoms and findings in the same season of the same year and therefore exposed to same antigens. Especially with the use of medications, via repeated osdi and oxford evaluations the drugs side effects could be evaluated. In the study no difference was found between drugs for side effects.

A further limitation in our study was its retrospective nature, based on file data. But so, participants with similar age groups and similar severity could be selected. Different researchers made pre- and post-treatment evaluations for most patients. This may have led to differences especially in the questioning of symptoms. In addition, we could not study tearing and blood IGE level in patients. This may have compromised our evaluation of the severity of the allergy and the homogeneous distribution of the sample.

\section{CONCLUSION}

Allergic conjunctivitis is a chronic, inflammatory eye disease which significantly affects the comfort of the patient. Olopatadine $0.1 \%$, ketotifen $0.025 \%$ and emedastine $0.05 \%$, which are currently frequently used, all help to improve the symptoms and findings of AC. In our study, we demonstrated a similar efficacy of olopatadine $0.2 \%$ single dose instillation per day to that of other antiallergic drugs used twice daily. The halving of the number of daily doses facilitates patients' compliance with treatment. However, there is a need for further comparative studies that have large participiants and have long time survey to gain a more complete understanding of the efficacy of single daily dose olopatadine $0.2 \%$.

\section{ETHICS APPROVAL AND CONSENT TO PARTICIPATE}

The study has been approved by the Ethics Committee of Maltepe University. 


\section{HUMAN AND ANIMAL RIGHTS}

No Animals were used in this research. All human research procedures followed were in accordance with the ethical standards of the committee responsible for human experimentation (institutional and national), and with the Helsinki Declaration of 1975, as revised in 2013.

\section{CONSENT OF PUBLICATION}

An informed written consent was taken from all the patients when they were enrolled.

\section{CONFLICT OF INTERESTS}

The authors declare no conflict of interest, financial or otherwise.

\section{ACKNOWLEDGMENTS}

The authors declare that they have no conflict of interest. The research did not receive specific funding and was not performed as part of the employment of the authors. The data used to support the findings of this study may be provided upon request and the data should be submitted as an additional information file with email interaction.

Help for English editing was received from 'Enago' service.

\section{REFERENCES}

[1] Baab S, Kinzer EE. Conjunctivitis, Allergic StatPearls. Treasure Island, FL: StatPearls Publishing StatPearls Publishing LLC 2017.

[2] Takamura E, Uchio E, Ebihara N, et al. Japanese guidelines for allergic conjunctival diseases 2017. Allergology international : Official J Japanese Soc Allergol 2017 ; 66(2): 220-9. [http://dx.doi.org/10.1016/j.alit.2016.12.004]

[3] Meier E, Narvekar A, Iyer GR, et al. Pharmacokinetics and safety of olopatadine hydrochloride $0.77 \%$ in healthy subjects with asymptomatic eyes: data from 2 independent clinical studies. Clin Ophthalmol 2017; 11: 669-81. [http://dx.doi.org/10.2147/OPTH.S126690] [PMID: 28435218]

[4] Ventura MT, Scichilone N, Paganelli R, et al. Allergic diseases in the elderly: Biological characteristics and main immunological and nonimmunological mechanisms. Clin Mol Allergy 2017; 15: 2.

[http://dx.doi.org/10.1186/s12948-017-0059-2] [PMID: 28174512]

[5] Torkildsen G, Narvekar A, Bergmann M. Efficacy and safety of olopatadine hydrochloride $0.77 \%$ in patients with allergic conjunctivitis using a conjunctival allergen-challenge model. Clin Ophthalmol 2015; 9: 1703-13. [http://dx.doi.org/10.2147/OPTH.S83263] [PMID: 26392751]

[6] Mizoguchi T, Ozaki M, Ogino N. Efficacy of $0.05 \%$ epinastine and $0.1 \%$ olopatadine for allergic conjunctivitis as seasonal and preseasonal treatment. Clin Ophthalmol 2017; 11: 1747-53. [http://dx.doi.org/10.2147/OPTH.S141279] [PMID: 29026285]

[7] Ackerman S, Smith LM, Gomes PJ. Ocular itch associated with allergic conjunctivitis: Latest evidence and clinical management. Ther Adv Chronic Dis 2016; 7(1): 52-67.

[http://dx.doi.org/10.1177/2040622315612745] [PMID: 26770669]

[8] CADTH Rapid response reports. Olopatadine for the treatment of allergic conjunctivitis: A review of the clinical efficacy, safety, and costeffectiveness. Ottawa (ON): Canadian agency for drugs and technologies in health copyright (c) 2016 canadian agency for drugs and technologies in health 2016.

[9] Iyer GR, Cason MM, Womble SW, Li G, Chastain JE. Ocular pharmacokinetics comparison between $0.2 \%$ olopatadine and 0.77\% olopatadine hydrochloride ophthalmic solutions administered to male New Zealand white rabbits. Journal ocular pharmacology and therapeutics: The Official J Assoc Ocular Pharmacol Therapeutics 2015; 31(4): 204-10. [http://dx.doi.org/10.1089/jop.2014.0140]

[10] Ozcan AA, Ersoz TR, Dulger E. Management of severe allergic conjunctivitis with topical cyclosporin a $0.05 \%$ eyedrops. Cornea 2007; 26(9): 1035-8.

[http://dx.doi.org/10.1097/ICO.0b013e31812dfab3] [PMID: 17893529]

[11] Liu RF, Wu XX, Wang X, Gao J, Zhou J, Zhao Q. Efficacy of olopatadine hydrochloride $0.1 \%$, emedastine difumarate $0.05 \%$, and loteprednol etabonate $0.5 \%$ for Chinese children with seasonal allergic conjunctivitis: A randomized vehicle-controlled study. Int Forum Allergy Rhinol 2017; 7(4): 393-8.

[http://dx.doi.org/10.1002/alr.21882] [PMID: 27869354]

[12] Saban DR, Calder V, Kuo CH, et al. New twists to an old story: Novel concepts in the pathogenesis of allergic eye disease. Curr Eye Res 2013; 38(3): 317-30.

[http://dx.doi.org/10.3109/02713683.2012.747617] [PMID: 23281793] 
[13] Mounsey AL, Gray RE. Topical antihistamines and mast cell stabilizers for treating allergic conjunctivitis. Am Fam Physician 2016; 93(11): 915-6. [PMID: 27281835]

[14] Carr W, Schaeffer J, Donnenfeld E. Treating allergic conjunctivitis: A once-daily medication that provides 24-hour symptom relief. Allergy Rhinol (Providence) 2016; 7(2): 107-14 [http://dx.doi.org/10.2500/ar.2016.7.0158] [PMID: 27466061]

[15] Avunduk AM, Tekelioglu Y, Turk A, Akyol N. Comparison of the effects of ketotifen fumarate $0.025 \%$ and olopatadine HCl 0.1\% ophthalmic solutions in seasonal allergic conjunctivities: A 30-day, randomized, double-masked, artificial tear substitute-controlled trial. Clin Ther 2005; 27(9): 1392-402. [http://dx.doi.org/10.1016/j.clinthera.2005.09.013] [PMID: 16291412]

[16] Borazan M, Karalezli A, Akova YA, Akman A, Kiyici H, Erbek SS. Efficacy of olopatadine HCI 0.1\%, ketotifen fumarate 0.025\%, epinastine HCI $0.05 \%$, emedastine $0.05 \%$ and fluorometholone acetate $0.1 \%$ ophthalmic solutions for seasonal allergic conjunctivitis: A placebocontrolled environmental trial. Acta Ophthalmol 2009; 87(5): 549-54. [http://dx.doi.org/10.1111/j.1755-3768.2008.01265.x] [PMID: 18631332]

[17] D'Arienzo PA, Leonardi A, Bensch G. Randomized, double-masked, placebo-controlled comparison of the efficacy of emedastine difumarate $0.05 \%$ ophthalmic solution and ketotifen fumarate $0.025 \%$ ophthalmic solution in the human conjunctival allergen challenge model. Clin Ther 2002; 24(3): 409-16.

[http://dx.doi.org/10.1016/S0149-2918(02)85042-1] [PMID: 11952024]

[18] Hida WT, Nogueira DC, Schaefer A, Dantas PE, Dantas MC. Comparative study between $0.025 \%$ ketotifen fumarate and 0.1\% olopatadine hydrochloride in the treatment of vernal keratoconjunctivitis. Arquivos Brasileiros de Oftalmologi 2006; 69(6): 851-6.

[19] Schoch C. Effect of ketotifen fumarate, olopatadine, and levocabastine on ocular active anaphylaxis in the guinea pig and ocular immediate hypersensitivity in the albino rat. Ocul Immunol Inflamm 2005; 13(1): 39-44. [http://dx.doi.org/10.1080/09273940590909167] [PMID: 15804768]

[20] Ganz M, Koll E, Gausche J, Detjen P, Orfan N. Ketotifen fumarate and olopatadine hydrochloride in the treatment of allergic conjunctivitis: A real-world comparison of efficacy and ocular comfort. Adv Ther 2003; 20(2): 79-91. [http://dx.doi.org/10.1007/BF02850255] [PMID: 12836808]

[21] Varguez-Rodríguez ME, Hernández-López A, Gómez-Dávila RdeL. Comparison of olopatadin and ketotifen in the treatment of allergic conjunctivitis. Rev Med Inst Mex Seguro Soc 2009; 47(4): 399-404. [PMID: 20553645]

[22] Lanier BQ, Finegold I, D’Arienzo P, Granet D, Epstein AB, Ledgerwood GL. Clinical efficacy of olopatadine vs epinastine ophthalmic solution in the conjunctival allergen challenge model. Curr Med Res Opin 2004; 20(8): 1227-33. [http://dx.doi.org/10.1185/030079904125004330] [PMID: 15324525]

[23] Berdy GJ, Spangler DL, Bensch G, Berdy SS, Brusatti RC. A comparison of the relative efficacy and clinical performance of olopatadine hydrochloride $0.1 \%$ ophthalmic solution and ketotifen fumarate $0.025 \%$ ophthalmic solution in the conjunctival antigen challenge model. Clin Ther 2000; 22(7): 826-33. [http://dx.doi.org/10.1016/S0149-2918(00)80055-7] [PMID: 10945509]

[24] Abelson MB, Gomes PJ, Vogelson CT, et al. Clinical efficacy of olopatadine hydrochloride ophthalmic solution 0.2\% compared with placebo in patients with allergic conjunctivitis or rhinoconjunctivitis: A randomized, double-masked environmental study. Clin Ther 2004; 26(8): $1237-48$.

[http://dx.doi.org/10.1016/S0149-2918(04)80065-1] [PMID: 15476905]

[25] Abelson MB, Gomes PJ. Olopatadine 0.2\% ophthalmic solution: The first ophthalmic antiallergy agent with once-daily dosing. Expert opinion on drug metabolism \& toxicolog 2008; 4(4): 453-61.

[http://dx.doi.org/10.1517/17425255.4.4.453]

[26] Abelson MB, Spangler DL, Epstein AB, Mah FS, Crampton HJ. Efficacy of once-daily olopatadine 0.2\% ophthalmic solution compared to twice-daily olopatadine $0.1 \%$ ophthalmic solution for the treatment of ocular itching induced by conjunctival allergen challenge. Curr Eye Res 2007; 32(12): 1017-22. [http://dx.doi.org/10.1080/02713680701736558] [PMID: 18085465]

[27] Vogelson CT, Abelson MB, Pasquine T, et al. Preclinical and clinical antiallergic effect of olopatadine $0.2 \%$ solution 24 hours after topical ocular administration. Allergy and asthma proceedings 2004; 25(1): 69-75.

[28] Berger WE. Once-daily olopatadine ophthalmic solution $0.2 \%$ in the treatment of allergic conjunctivitis and rhinoconjunctivitis. Expert review of pharmacoeconomics \& outcomes research 2007; 7(3): 221-6. [http://dx.doi.org/10.1586/14737167.7.3.221]

[29] Ohno S. A multicenter, double-masked, randomized evaluation of olopatadine $0.2 \%$ using the conjunctival allergen challenge model in Japanese patients with allergic conjunctivitis. Nippon Ganka Gakkai zasshi 2012; 116(12): 1123-9.

(C) 2018 Erdogan and Cam.

This is an open access article distributed under the terms of the Creative Commons Attribution 4.0 International Public License (CC-BY 4.0), a copy of which is available at: (https://creativecommons.org/licenses/by/4.0/legalcode). This license permits unrestricted use, distribution, and reproduction in any medium, provided the original author and source are credited. 